\title{
Indonesian Educators' Knowledge and Beliefs about Teaching Children with Autism
}

\author{
By Budiyanto*, Kieron Sheehy ${ }^{\dagger}$, Helen Kaye ${ }^{*} \&$ \\ Khofidotur Rofiah ${ }^{\S}$
}

\begin{abstract}
There is a large number of children with autism who need to be taught within the Indonesian education system. A significant influence on how their needs are perceived are the epistemological and cultural beliefs of teachers. This research is the first to examine these issues in the context of the Indonesian government's intention to develop an inclusive education system. An analysis of 136 questionnaire responses from teachers and educational therapists indicated that although only a minority was aware of, or had been trained in, established autism interventions, children with autism are being taught within Indonesian schools. This included being taught within regular schools. The data suggest that having access to information about autism in the Bahasa Indonesia language plays a role in educators' beliefs about the stigmatization of teachers and parents of autistic children. Teachers' epistemological beliefs were found to be linked to their beliefs in inclusive education. This research suggests that is essential for educational research to acknowledge the influence of the cultural milieu within which inclusive education is being developed. The implications of this research for how the development of inclusive education can be supported within Indonesia are discussed.
\end{abstract}

Keywords: autism, inclusion, Indonesia, teachers' beliefs.

\section{Introduction}

Inclusive education is a world-wide movement, inspired by the Universal Declaration of Human Rights. At its heart is the shared belief in "education for all" where that all children, including those labelled as having special educational needs and disabilities, are able to have equal access to education with their peers. This belief is reflected in associated policies such as the Convention on Rights of People with Disabilities, which is explicit that "Parties shall ensure an inclusive education system at all levels ..." (Department of Economic and Social Affairs, 2011, Article 24). Indonesia is the most diverse multi-ethnic nation in the world (Direktorat Pembinaan Sekolloah, 2008) and the government has set the challenge of implementing inclusive education for all school-age children in light of the "Education for All" Agenda (Budiyanto, 2011; Ramos-Mattoussi \& Milligan, 2013). The beginning of inclusive education in Indonesia can be seen in 2001,

\footnotetext{
*Senior Lecturer, State University of Surabaya, Surabaya, Indonesia.

'Professor of Education (Innovation Pedagogies), the Open University, UK.

'Deputy Associate Dean, Faculty of Arts and Social Sciences, The Open University, UK.

${ }^{\S}$ Lecturer, State University of Surabaya, Surabaya, Indonesia.
} 
when the Directorate for Special Education supported the first inclusive pilot school in Yogyakarta. Following this the Minister of Education's 2003 directive (the Direction Letter of the Directorate General of Primary and Secondary Education No 380/C.66/MN/2003) was for each region to develop at least four inclusive schools. This occurred in parallel to the Education Law 2003, which mandated free basic education for all and devolved school management to a local level. By 2008, 925 inclusive "pioneer" schools had been created (Sunardi, Yusuf, Gunarhadi, Priyono, \& Yeager, 2011). Subsequent policies have endeavoured to facilitate inclusive education at national and regional levels. For example, a 2009 decree (Decree of the Minister of Education No 70-2009) stated that every district should have an inclusive high school and that every sub-district should have one inclusive primary and one inclusive secondary school. Block grants were given to support these schools [For detailed analysis of the development and range of policies see (Wibowo \& Muin, 2018)].

In Indonesia, schools can be categorized as regular, inclusive or special, and all three have continued to exist (Aprilia, 2017). Regular schools typically do not admit pupils with disabilities or special educational needs. These children might be taught in 'Sekolah Luar Biasa' (special schools), which traditionally have been orientated towards specific disability categories such as deafness (Purbani, 2013). The devolvement of school management to local levels has created a wide variation in school admission practices across special and regular schools (Aprilia, 2017) and this is seen as having a negative effect on school access rates, particularly in rural areas (Kristiansen, 2006). This local government at district (kota) level applies to state education. However, all special schools are governed at the broader provincial level. In addition, there is a religious school system, governed by Ministry of Religious Affairs (MORA) (Suwaryani, 2008).

Whilst national laws may apply to religious schools, as with state schools, access by disabled children can be problematic (Afrianty \& Soldatic, 2016).

One consequence of the inclusive education initiative is that children, who might previously have been excluded from education in regular and special schools (Tucker, 2013), are attending inclusive classrooms (Padmadewi \& Artini, 2017). The majority of these children have intellectual disabilities (Sunardi et al., 2011). Given the co-morbidity between intellectual disabilities and autism (Roberts, \& Williams, 2016; Tekola et al., 2016), it is likely that many children with autism are now attending inclusive schools. Children who are given the diagnostic label of autism, or the more recent category of autistic spectrum disorders (ASD) (Roberts \& Williams, 2016) will experience a severe impairment in their reciprocal social interactions (Baxter et al., 2015). Although these characteristics vary significantly between individual children, the majority will have some form of intellectual disability (Herring, 2016).

There is relatively little research regarding autism in Indonesia (Febrian Kristiana \& Widavant, 2015) and no definitive national picture of how many children in Indonesia are affected by autism (Sakya, Santosa, \& Bagus, 2017). This is partly because of differing diagnostic practices, and significant variations in access to opportunities for a diagnosis across such a geographically and culturally diverse nation (Sidjaja \& Newcombe, 2016) However, it is certain that there are a 
large number of children with autism in Indonesia. The main epidemiological study, to date, occurred in Yogokarta, one of the nation's largest cities, and indicated a prevalence of autism (for children born between 1984 and 1991) of $12 / 10,000(0.1 \%)$ (Wignyosumarto, Mukhlas, \& Shirataki, 1992). Although this epidemiological research has not been replicated (Riany, Cuskelly, \& Meredith, 2016; Sidjaja \& Newcombe, 2016), there is some evidence that the diagnosis of autism in Indonesia has subsequently increased (Tucker, 2013). This is in line with recent global reviews, in which rates of autism in children are much higher than previously thought, partly because diagnostic approaches have become more widely used worldwide (Roth, 2017). Estimates of the incidence of autism vary over time and also between countries (Baxter et al., 2015) For example international estimates range between approximately "one in every 150 children" $(0.67 \%)$. (Riany et al., 2016, p. 2) to one in one hundred (Department of Health, 2013), to $1.14 \%$ of all Indonesia's 237.5 million people (Lestari, Herini, \& Gamayanti, 2017). The various estimates have been accompanied by an increased awareness of autism, reflected in an increasing number of alternative therapy centres for autism (Windiani, Soetjiningsih, Adnyana, \& Lestari, 2016), several government and health organizations providing family support, and 24 provincial autism centers (Lestari et al., 2017).

Comparative international research suggests that, in other countries, children with autism are being educated in settings that range across a mainstream-tospecial school-excluded continuum (Rix, Sheehy, Fletcher-Campbell, Crisp, \& Harper, 2013). Given the diverse nature of autism it is possible that many children with autism might attend regular Indonesian schools, however data on this issue is absent outside of a single case study report (Padmadewi \& Artini, 2017).

It was reported in 2008 that there were 638,000 children, diagnosed with autism, in Indonesian special schools (Riany et al., 2016). However, there is a lack of more recent data on this issue (Bella, 2018) and so the current number of children with autism in regular, special and inclusive school settings remains unclear. This lack of clarity is exacerbated by a national situation in which there are low rates of birth registration, especially in rural areas. Many schools require these registration documents as a precondition for enrolment, and so children with disabilities from poorer rural families are excluded from school, and hence from identification within educational records (Sumner, 2015). However, the data that is available, although partial, indicates that there is a significant number of children with autism who will need to be taught within Indonesia's education system. This is a significant issue in relation to developing appropriate educational practices and support as Indonesia implements its policy of inclusive education.

The Inclusive Indonesian Classrooms project is a joint endeavour between the State University of Surabaya, Indonesia, and the Open University, United Kingdom. It aims to develop pedagogical strategies and teaching approaches to facilitate inclusive teaching (Sheehy \& Budiyanto, 2014). Examination of effective inclusive practice highlights the importance of using social interactions as an educational tool (Littleton \& Mercer, 2013; Rix, Hall, Nind, Sheehy, \& Wearmouth, 2006). However, this way of teaching can only benefit children if they can access the social interactions that mediate the classroom's curricular 
activities and resources. This is a profound issue for children with autism who experience difficulties with language and communication (UNESCO, 2009). This issue of autism has therefore become one focus for the Inclusive Classrooms project. A starting point for exploring this issue was a need to gain insights into Indonesian teachers' awareness of autism and different teaching approaches that are associated with autism, and their beliefs about where children with autism are best educated.

An enormous variety of teaching approaches and interventions are used internationally for children with autism, possibly more than associated with any other category of special educational need (Bond, Symes, Hebron, Humphrey, \& Morewood, 2016; Guldberg, Parsons, MacLeod, Jones, Prunty, \& Balfe, 2011). Regarding Indonesia, the current study reviewed publications between 20072017, that were accessible online and addressed interventions for children with autism in Indonesia. From this review 13 approaches emerged. A brief description of each approach is given in Table 1, with references to more detailed information.

Table 1. Teaching Approaches and Interventions Indicated Within Research Accounts of Indonesian Educational Practice for Children with Autism

\begin{tabular}{|c|c|}
\hline Name of Approach & Brief Description \\
\hline $\begin{array}{l}\text { Applied Behaviour Analysis } \\
\text { (Makrygianni, Gena, Katoudi, \& } \\
\text { Galanis, 2018) } \\
\text { Lovaas Therapy } \\
\text { (Jordan, Jones, \& Murray, 1998) }\end{array}$ & $\begin{array}{l}\text { These approaches are built on behavioural methods, } \\
\text { typically breaking identified tasks into discrete steps } \\
\text { and teaching these through reinforcing appropriate } \\
\text { behaviors, }\end{array}$ \\
\hline $\begin{array}{l}\text { Treatment and Education of } \\
\text { Autistic and related } \\
\text { Communication handicapped } \\
\text { CHildren (TEACCH) } \\
\text { (Mesibov \& Shea, 2010) }\end{array}$ & $\begin{array}{l}\text { A key feature of this approach is examining how the } \\
\text { child 'reads' their environment, and physically } \\
\text { structuring the child's space to facilitate their } \\
\text { learning. For example, through visual maps, } \\
\text { schedules and symbolic representation of events. }\end{array}$ \\
\hline $\begin{array}{l}\text { Biomedical Intervention } \\
\text { (Mire, Gealy, Kubiszyn, Burridge, } \\
\text { \& Goin-Kochel, 2017). }\end{array}$ & $\begin{array}{l}\text { This category encompasses special diets, or dietary } \\
\text { supplements, chelation, detoxification and } \\
\text { interventions that are deemed helpful in addressing } \\
\text { biomedical problems that have been suggested as } \\
\text { linked to or underpinning autism. }\end{array}$ \\
\hline $\begin{array}{l}\text { Chinese alternative medicines } \\
\text { (Tucker, 2013) }\end{array}$ & $\begin{array}{l}\text { This includes reflexology, acupuncture and } \\
\text { acupressure. }\end{array}$ \\
\hline $\begin{array}{l}\text { Javanese folk healing } \\
\text { (Tucker, 2013) }\end{array}$ & $\begin{array}{l}\text { This might involve buying and drinking herbal tonics } \\
\text { and remedies. }\end{array}$ \\
\hline $\begin{array}{l}\text { Religious intervention } \\
\text { (Fithri, 2011) }\end{array}$ & $\begin{array}{l}\text { Religious practices and ritual that are deemed helpful } \\
\text { to pupils with autism, and in improving their } \\
\text { educational lives. }\end{array}$ \\
\hline $\begin{array}{l}\text { Floortime [Developmental, } \\
\text { Individual- Difference, } \\
\text { Relationship-Based } \\
\text { (DIR)/Floortime] } \\
\text { (Greenspan \& Wieder, 1997; } \\
\text { Pajareya \& Nopmaneejumruslers, } \\
\text { 2011) }\end{array}$ & $\begin{array}{l}\text { An approach that focuses on facilitating meaningful } \\
\text { interpersonal relationships, through spontaneous } \\
\text { social interactions }\end{array}$ \\
\hline Son-Rise Program & Most usually used as a home-based parent-run \\
\hline
\end{tabular}




\begin{tabular}{|l|l|}
\hline (Williams, 2006) & $\begin{array}{l}\text { intervention. It is a 1:1 child-led approach in which } \\
\text { parents join in with the child's chosen activities. }\end{array}$ \\
\hline $\begin{array}{l}\text { PECS (Picture Exchange } \\
\text { (Bommunication System) }\end{array}$ & $\begin{array}{l}\text { A systematic and structured programme to teach } \\
\text { spontaneous social-communication skills to children } \\
\text { with autism. It uses different types of symbols such } \\
\text { as photographs and pictures to facilitate meaningful } \\
\text { interactions. }\end{array}$ \\
\hline $\begin{array}{l}\text { Signalong Indonesia } \\
\text { (Budiyanto, Sheehy, Kaye, \& } \\
\text { Rofiah, 2017; Jauhari, 2017) }\end{array}$ & $\begin{array}{l}\text { This is a keyword signing approach developed in } \\
\text { Indonesia to support inclusive class teaching in } \\
\text { Indonesia. It also has a series of classroom } \\
\text { communication symbols. }\end{array}$ \\
\hline $\begin{array}{l}\text { Sensory Integration } \\
\text { (Ottenbacher, 1982) }\end{array}$ & $\begin{array}{l}\text { Usually supported by Occupational therapists, this } \\
\text { approach uses various physical activities to address } \\
\text { neuropsychological dysfunctions, for example in } \\
\text { relation to a child's processing of vestibular-related } \\
\text { sensory information. }\end{array}$ \\
\hline $\begin{array}{l}\text { Gentle Teaching } \\
\text { (McGeee \& Brown, 1988) }\end{array}$ & $\begin{array}{l}\text { A non-aversive approach to developing positive } \\
\text { behaviors within respectful, safe, relationships. }\end{array}$ \\
\hline $\begin{array}{l}\text { Daily Life Therapy (Seikatsu } \\
\text { Ryouhou) } \\
\text { (Dempsey \& Foreman, 2001) }\end{array}$ & $\begin{array}{l}\text { This is a 24 hours curriculum which foregrounds the } \\
\text { importance of physical activity to reduce anxiety and } \\
\text { establish daily rhythms. Group dynamics are } \\
\text { important and children develop these social skills } \\
\text { within predictable daily routines. }\end{array}$ \\
\hline
\end{tabular}

Currently there is no research into Indonesian teachers' beliefs about teaching children with autism. The difficulties experienced by these children, their families and teachers are compounded significantly in countries where there is a low awareness of autism, combined with stigmatization and limited or developing service provision (Tekola et al., 2016). It is therefore important to research and understand these issues in relation to Indonesia and its educational system. A key influence on children's educational placement and experience is the belief of educators concerning whether children with autism require a specialist and separate educational placement to their peers. Indonesian children with autism have been a group at high risk of being excluded from education. This has been influenced by their increased likelihood of having severe learning difficulties, experiencing significant barriers to communication within schools, and the social stigmatization of disability (Riany, Cuskelly, \& Meredith, 2016; Tekola et al., 2016). These factors can interact to create major barriers to educational access.

"One founder of a private school for autistic children said to me that in a country where many typical children don't have access to education, education for disabled or autistic children "is not even seen as a responsibility, let alone a right" (Puspita, 2010, cited in Tucker, 2013, p. 54)

Consequently, there is a situation in which, even where special schools exist, they might not admit children with autism (Suwaryani, 2008). It has been suggested that a contributing factor to society's perceptions of children with 
autism is a lack of Indonesian-language (Bahasa Indonesia) information (Adinugroho, 2010). Rainy, Cuskelly, \& Meredith, (2016) concluded that

"a large percentage of Indonesians still have little understanding about autism (and other disabilities) due to limited access to media and other health information. This is particularly likely to apply to those who live in small cities and rural areas" (Riany, Cuskelly, \& Meredith, 2016, p. 2)

In the absence of access to information, the importance of existing cultural beliefs is magnified and can impact significantly upon how parents and teachers behave with regard to children with autism. However, " little is known about cultural beliefs regarding children with autism within Indonesian cultures" (Riany, Cuskelly, \& Meredith, 2016, p. 1). Riany, Cuskelly, \& Meredith's (2016) small qualitative study was the first research to examine parental beliefs in this area and uncovered a range of beliefs in which, for example, beliefs about taboo or the breaking of karma lead to the stigmatization of autism (Riany, Cuskelly, \& Meredith, 2016, 2016). Their research concluded that awareness of these beliefs was important because

"...the community's perceptions regarding autism will be influential in determining social and institutional responses to the needs of children with autism and those of their families" (Riany, Cuskelly, \& Meredith, 2016, 2016)

Subsequently, research with seven caregivers in rural West Borneo found that their ability to care for their children was affected by negative attitudes and actions from their family and the community (Lestari, Herini, \& Gamayanti, 2017). This included " verbal violence, violent threat, and keeping away from children with ASD [Autism]" (Lestari, Herini, \& Gamayanti, 2017, p. 323)

Research into Indonesian teachers' beliefs is sparse and only one study, to date, has partly examined Indonesian teachers' beliefs about the nature of autism. Febrian and Widavant (2015) asked five open-ended questions to early childhood teachers, in Central Java. Two of these questions asked about their knowledge and experience of autism ( Febrian \& Widavant 2015). They found that approximately $88 \%$ of the teachers had no knowledge regarding autism. Those with some knowledge and experience believed that autism was 'the same as being crazy' ( $p$ 57). Febrian and Widavant (2015) concluded that there was a significant misunderstanding amongst the early childhood service teachers about the nature of autism. This current research emerged from discussions with teachers and is the first study to explore Indonesian teacher beliefs about teaching children with autism, and in relation to inclusive education. It sought to examine the relationship between teachers' epistemological beliefs and beliefs about the nature of autism, and to map the teaching approaches with which they are familiar. This research aimed to steer the directions of future research in the Inclusive Classrooms project and, more broadly, inform the training of teachers of children with autism in Indonesia. 


\section{Method}

\section{The Questionnaire}

A questionnaire was developed to collect data about teacher's beliefs and knowledge (see Appendix 1). Q 1, 2 and 17 were based on questionnaire research examining Indonesian teachers' pedagogic beliefs (Sheehy \& Budiyanto, 2015). Drawing on this research, three "teacher variables" questions were added to the questionnaire (Appendix 1, Questions 1, 2 and 17), which had been found to influential in relation to beliefs about inclusive and special education. Teachers beliefs epistemological beliefs have previously been researched using Questions 3, 4,6 and 8 (OECD, 2009; Sheehy, Budiyanto, Kaye, \& Rofiah, 2017), and so these were included to consider social constructivist (Q3 and 4) and traditional direct transmission (Q 6 and 8) beliefs about learning. The notion of happiness of different types (Senang and Suka) has been suggested as a central issue for Indonesian pedagogy (Budiyanto, Sheehy, Kaye, \& Rofiah, 2017), and so items 12 and 13 asked about this. The notion that autism is caused by parents who break a taboo or as the result of karma, has been identified as a common belief amongst the general public, and a significant factor in shaping people's responses to autism (Riany et al., 2016). Question 14 sought to find out the extent of these beliefs in this sample of Indonesian teachers. Previous research has identified that parents of children with autism (Riany, Cuskelly, \& Meredith, 2016) and teachers of children with special educational needs (Budiyanto, Sheehy, Kaye, \& Rofiah, 2017) can be stigmatized. Question 15 asks participants about this issue. There has been a rapid increase in the number of interventions and therapeutic centres for children with autism in Indonesia (Windiani, Soetjiningsih, Adnyana, \& Lestari, 2016). However, many of these interventions are not evidence-based (Roberts \& Williams, 2016). Furthermore, a long term ethnographic research study indicated that that many special education and regular school teachers may not 'have never heard of autism, let alone received training on how to educate autistic students' (Tucker, 2013, p. 56). Question 16 therefore lists interventions that have been identified as being used in Indonesia and asks teachers to indicate the degree to which they are aware of, or have received training in, each. Although a wealth of information about autism and teaching children with autism can be sourced online, an issue for parents and professionals has been access to good Bahasa Indonesia translations (Adinugroho, 2010; Tucker, 2013). Question 13 asks about the extent to which this situation exists for teachers. International research suggests that teachers commonly report a belief that they lack the skills to teach children with special educational needs (Rix, Sheehy, Fletcher-Campbell, Crisp, \& Harper, 2013). Question 19 explores this issue in relation to Indonesian teachers and children with autism.

Question 20 asks teachers about where they feel children with autism are best educated and also about the belief that children with autism have special abilities. Research evidence suggests the latter belief can influence the former belief (Cassady, 2011). Question 21 examines the suggestion (Tucker, 2013) that parents' financial status is a major influence on having a child diagnosed with 
autism and then obtaining an appropriate education or early intervention for them. Finally, Question 22 is an open question asking "What sort of training or information would be most helpful to you to support children with autism in your school?"

The research team comprised native Bahasa Indonesian and English language speakers. The questions were written in English and then back translated between Bahasa Indonesian and English. However, when creating and adapting questionnaires for different cultures "back-translation has moderate impact, whereas [an] expert committee helps to ensure accurate content" (Epstein, Osborne, Elsworth, Beaton, \& Guillemin, 2015, p. 360). Therefore, the questionnaire translation was also discussed by an expert committee that included teachers, psychologists and a translator. The questions were then revised and mixed together to create a hard copy questionnaire.

\section{Procedure}

Ethics. The research followed the British Psychological Society ethical guidance (British Psychological Society, 2014) and was supported by the Ethics committee of the Open University. Each questionnaire contained information about the research project to support participants' informed consent.

Participants. The questionnaire was distributed at a national teachers' conference in East Java. Teachers from across Indonesia attended the conference, participation was voluntary and teachers could choose to return their completed questionnaires to boxes placed in the conference foyer. An estimated 350 people attended the conference, with 136 returning a completed questionnaire giving a return rate of approximately $43 \%$. The majority of the sample was teachers $(56 \%)$ or student teachers (28\%), with a small number of others e.g. Psychologists (10\%) and therapists $(3 \%)$. The questionnaire respondents were working primarily in regular $(30 \%)$ and $(28 \%)$ inclusive schools, with $6 \%$ working special schools and approximately $20 \%$ categorizing their school type as "other".

\section{Results}

Over half of the participants (54\%) had contact with autistic children as part of their professional role and $34 \%$ had contact with autistic children outside of their professional work. i.e. socially.

As might be expected teachers from inclusive and special schools were the most likely to work with children with autism (Pearson chi square, $p=0.007$ two tailed). Only 9 participants were from special schools and all but one worked with children with autism. However, $41 \%$ of teachers from regular schools also reported that they worked with children with autism

Previous research has suggested that professional contact is related to beliefs and attitudes towards children with special educational needs (Avramidis \& Norwich, 2002). The current research examined this and also differences in relation 
to experience of children with autism. Although nearly all (89.9\%) respondents agreed that children have the right to education with their peers, their beliefs about what this means varied in association with their experience and the type of school in which they taught. Having professional contact and the type of school that a teacher works in was associated with differences in teachers' beliefs about where children with special educational needs and autism should be educated. Those who had professional contact with children with autism were less likely to believe that children with SEN (in general) learn most effectively in a special school, rather than a mainstream/regular school $(\mathrm{M}=2.99, \mathrm{SD}=1.0)$, in comparison to teachers without such contact $(\mathrm{M}=2.56, \mathrm{SD}=1.3 ; \mathrm{t}=2.29, \mathrm{df}=131, \mathrm{p}=0.027)$. Those who had this contact were also less likely to believe $(\mathrm{M}=2.58, \mathrm{SD}=1.13$, ) that children with autism should be taught in special schools, than the no contact group $(\mathrm{M}=2.13$, SD $=1.0, \mathrm{t}=2.24, \mathrm{df}=125, \mathrm{p}=0.017$ ).

Although most respondents (89.9\%) agreed or strongly agreed that 'All Children have the right to education with their peers', their responses to questions regarding school placement varied in relation to their type of school. Teachers who worked in regular schools agreed more strongly $(\mathrm{M}=2.05, \mathrm{SD}=.89)$ than teachers in inclusive schools $(\mathrm{M}=2.65, \mathrm{SD}=1.18, \mathrm{t}=-2.59, \mathrm{df}=81, \mathrm{p}=0.011)$ that children with autism should be educated in special schools and also that all children with SEN require education in special schools (Regular school teachers $M=2.4$, $\mathrm{SD}=1.1$, Inclusive school teachers $\mathrm{M}=3.13, \mathrm{SD}=1.1, \mathrm{t}=12.77, \mathrm{df}=81, \mathrm{p}=0.007$ ).

\section{Descriptive Analysis}

The majority of participants had not heard of any of the identified approaches. However, some respondents used, or been trained to use, particular approaches and this is illustrated in Figure 1.

Figure 1. Percentage of Participants that have been trained in or had used Specific Interventions

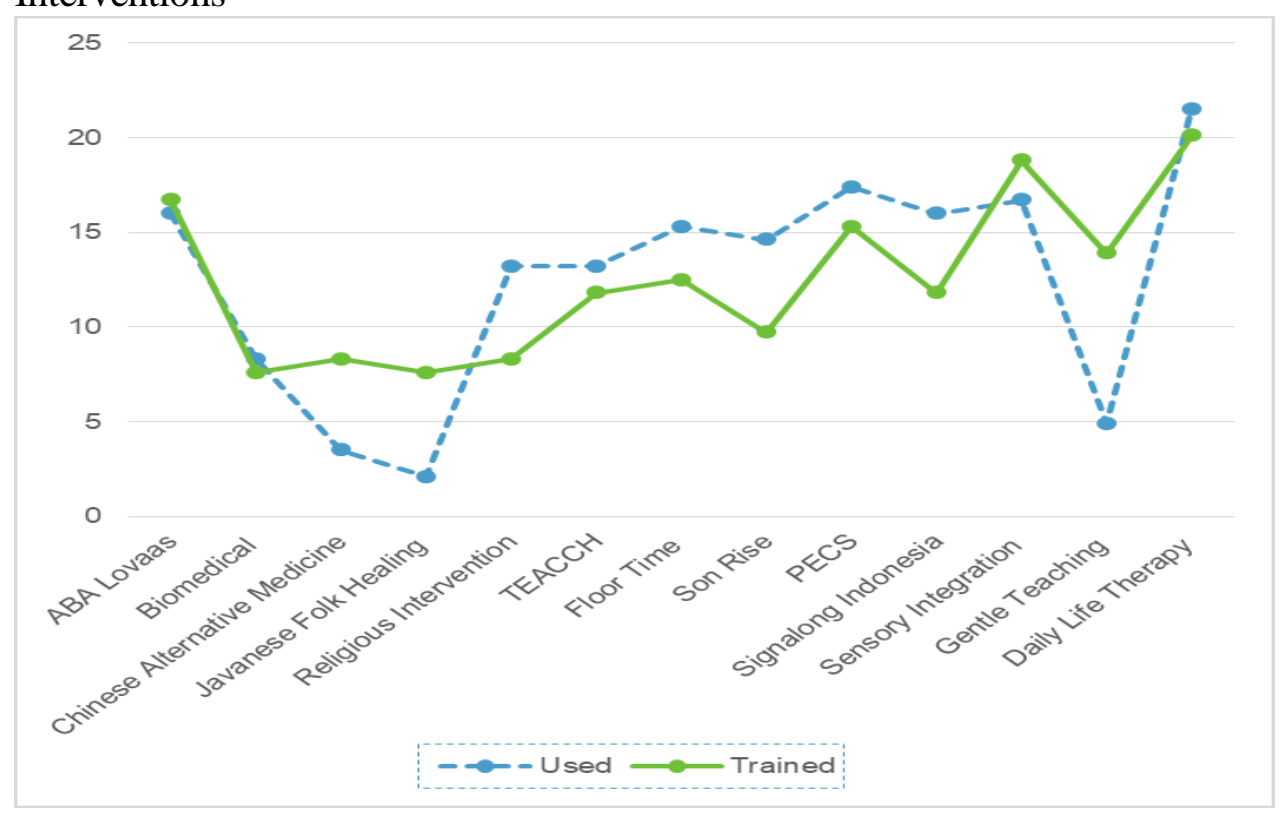


The five most commonly used approaches were ABA Lovaas (Ariyanto et al., 2017), Signalong Indonesia (Budiyanto, Sheehy, Kaye, \& Rofiah, 2017), Sensory Integration (Ottenbacher, 1982), PECS (Bondy, 2012) and Daily Life Therapy (Larkin \& Gurry, 1998). Examining which groups of respondents had been trained in these "top five" approaches indicated that the trained minority tended to be trained in more than one approach. This is illustrated in Figure 2.

Figure 2. The Percentage of Participant Groups Trained In the Five Most Popular Interventions

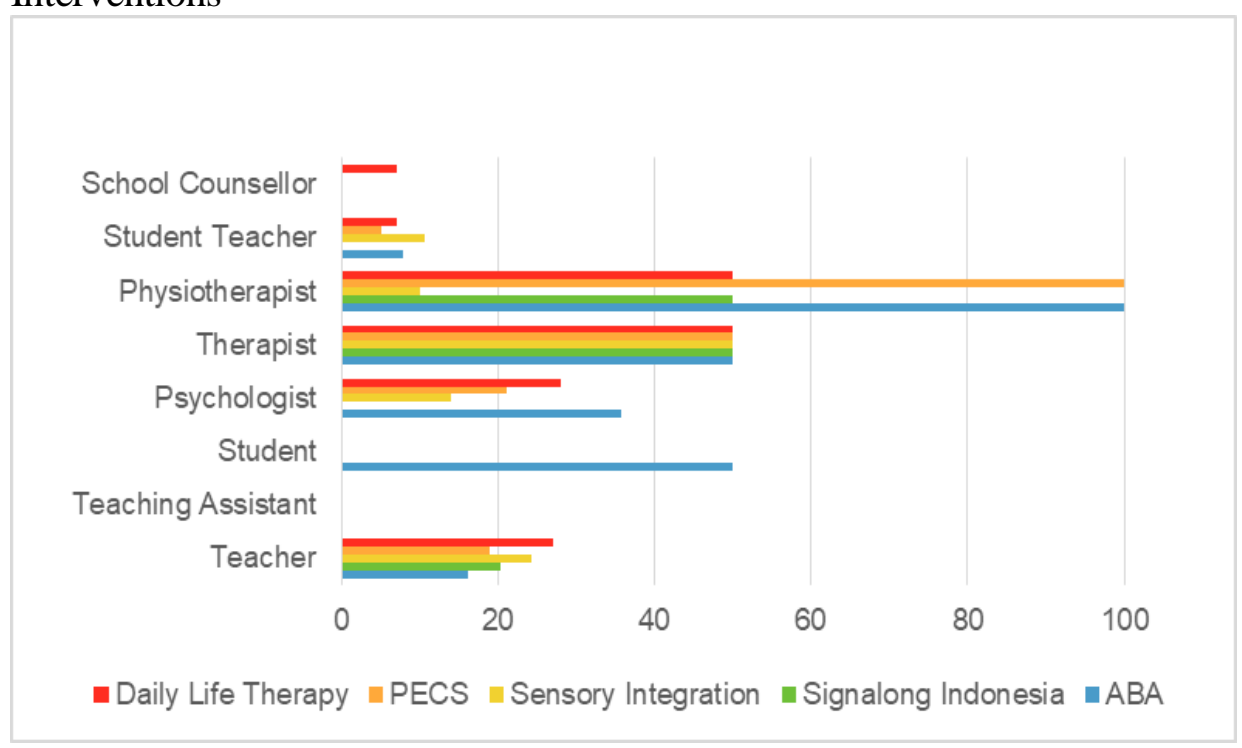

Beliefs and Taboo. Nearly one in five (17\%) of the participants reported that they had met teachers who believed that autism was caused by breaking a taboo, and $12 \%$ had met teachers who believed that autism was caused as the result of karma.

Stigmatisation. In relation to beliefs about stigmatisation, $30 \%$ of participants agreed (SA and A) that parents were stigmatised by their community if their child has autism, and $37.5 \%$ neither agreed nor disagreed with this. Almost a quarter (24\%) of participants agreed with the statement that teachers of children with autism are stigmatised by their community, and $32.6 \%$ neither agreed nor or disagreed. There was a positive correlation between a belief that parents were stigmatised and that teachers of children with autism were stigmatized (rho $=0.49$, $\mathrm{p}<0.01$, two tailed). There was also a negative correlation between a belief that parents are stigmatized and a belief that All children have a right to education with their peers $(\mathrm{rho}=-0.237, \mathrm{p}<0.001)$.

\section{Response Analysis}

The questionnaire data were reviewed for conducting a principal component analysis (PCA). Although the sample of 136 was less than in other studies (MacCallum,Widaman, Zhang \& Hong, 1999), it yielded a Kaiser-Meyer-Olkin 
(sampling adequacy) score of 0.782 indicating that distinctive reliable factors could be extracted (Beavers et al., 2013). This was supported by Bartlett's test of sphericity ( $\mathrm{p}<0.001)$. A PCA with Varimax rotation was carried out and informed by scree analysis, values below 0.35 were omitted. Five components were extracted see Table 2.

Table 2. Principle Component Analysis $(\mathrm{n}=136)$

Rotated Component Matrix ${ }^{\mathrm{a}}$

\begin{tabular}{|l|c|c|c|c|c|}
\hline \multirow{2}{*}{} & \multicolumn{5}{|c|}{ Component } \\
\hline & \multicolumn{1}{|c|}{1} & 2 & 3 & 4 & 5 \\
\hline Sensory Integration & .849 & & & & \\
\hline TEACCH & .820 & & & & \\
\hline PECS & .807 & & & & \\
\hline Floor Time & .806 & & & & \\
\hline Daily Life Therapy & .805 & & & & \\
\hline Biomedical interventions & .802 & & & & \\
\hline Son-Rise & .790 & & & & \\
\hline Religious Interventions & .775 & & & & \\
\hline Javanese Folk Healing & .772 & & & & \\
\hline Signalong Indonesia & .770 & & & & \\
\hline Gentle Teaching & .737 & & & & \\
\hline ABA Lovaas & .725 & & & & \\
\hline Chinese Alternative Medicine & .708 & & & & \\
\hline Happy/Senang teaching & & .873 & & & \\
\hline Regular Teachers/Special Training & & .817 & & & \\
\hline Happy/Suka teaching & & .803 & & & \\
\hline All Children Right to Edn with Peers & & .567 & & & \\
\hline Meaningful learning is social & & .521 & & & \\
\hline Income Access suitable education & & & .850 & & \\
\hline Income-Access Diagnosis & & & .815 & & \\
\hline Autism \& Special Talents/Abilities & & & .588 & & \\
\hline Autism-Mainstream Support & & & .492 & & \\
\hline Autism- Specialist Settings & & & & .756 & \\
\hline SEN requires Special School & & & & .723 & \\
\hline Autism Taught in Special School & & & .389 & .566 & \\
\hline Autism-Clear Answers & & & & .374 & \\
\hline Edn Potential Fixed at Birth & & & & & \\
\hline Average stays Average & & & .377 & & -.399 \\
\hline Parents-Stigmatised by Autism & & & & & \\
\hline Teachers-Stigmatised by Autism & & & & \\
\hline Access Bahasa Indonesia materials & & & & & \\
\hline Extacione & & & & & \\
\hline
\end{tabular}

Extraction Method: Principal Component Analysis.

Rotation Method: Varimax with Kaiser Normalization.

a. Rotation converged in 6 iterations.

PC1- Knowledge of interventions. As expected from the descriptive statistics, participants' responses to the 'interventions and approaches' questions indicated that the minority who have experience of one approach are likely to have 
experience of others too. Conversely those who lack knowledge of one are likely to lack knowledge of other approaches.

PC2. Social Constructivist, joyful teaching for all. This component indicates the associations between social constructivist epistemological beliefs, the importance of happiness (of different types) in pedagogy and a belief in all children having a right to education with their peers.

PC3. Mainstream education and special abilities. A belief that children with autism can do well in mainstream schools is associated with beliefs that autistic children have special talents and abilities, and that access to diagnosis and education depends on parental income. There is a positive association between these beliefs and access to information about autism written in Bahasa Indonesian.

PC4. Special schools for SEN pupils with direct transmission teaching. The beliefs that children with SEN and also those autism should attend special schools was associated with a belief in a 'clear answers' teaching approach. This item is taken as an indicator of direct traditional teaching methods (as opposed to social constructivist or problem solving approaches beliefs) (OECD, 2009).

PC5. Access to information and the stigmatization of Autism. There was a negative relationship between access to information in Bahasa Indonesia and beliefs in the stigmatisation of teachers and parents of children with autism. Respondents with less access to Bahasa Indonesia information were more likely to report that autism was stigmatizing.

Open Comments. Additional comments were provided by 77 respondents. All of these indicated a desire for training in relation to autism and all felt that this would be helpful in their roles as educators. Teachers (42\%) explicitly asked for training opportunities where they could practice and develop their skills. Although most teachers were not aware of autism related approaches, several requested training in specific approaches or areas, possibly prompted by the questionnaire itself. For example behaviour modification training (11\%), creating autism friendly environments $(6 \%)$ and language and communication approaches, such as Signalong Indonesia (8\%). Where training was requested, the preferred nature of this training was seminars and lesson study workshops (26\%). Lesson Study is an established approach in Japan (Fernandez, 2002) and is well designed for continuing professional development (Hiebert, Morris, \& Glass, 2003). This approach has an explicit practical pedagogic focus and has been used successfully in Indonesia (Subadi, Khotimah, \& Sutarni, 2013). Only one response requested training in addressing stigmatisation

\section{Discussion}

The participants' responses indicated that children with autism were being educated in a variety of schools in Indonesia, including within regular schools, and 
this reflects comparative research in other countries (Sheehy, Rix, FletcherCampbell, Crisp, \& Harper, 2013). This is the first Indonesian research to show that many regular school teachers are teaching children with autism, and challenges the suggestion that this group of children are necessarily unlikely to access even special education within Indonesia (Tucker, Finkelhor, Turner, \& Shattuck, 2013). However, because autism is such a diverse phenomenon further research is required to understand the individual factors associated with these responses and the nature of the provision that is being made for them. For example, in other countries children with autism who are intellectually able are included in mainstream, whilst others may be excluded, or included because of parental income (Alqahtani, 2012).

The results support Tucker's (2013) conclusion that most teachers have not received specific training in how to educate autistic students. Most teachers were unfamiliar with any of the teaching approaches that were considered, in a situation where many are teaching children with autism. This underlines the need for further research to explore, and assess the efficacy of, the pedagogical practices that are developing for children with autism within the Indonesian educational system outside of the "named approaches". Meta-analysis of research into teaching children with ASD indicates that such research has been culturally and ethnically narrow in its focus (West, et al., 2016). Researching Indonesian practice would help address this narrow focus and contribute to developing more sustainable impacts on classroom practice. The potential introduction of 'named' training approaches should acknowledge the nature of Indonesian pedagogical and cultural practices in relation to autism. Importing non-Indonesian approaches into inclusive classrooms requires critical reflection and evaluation, as the positive results obtained in Western research with narrow groups of participants may not translate well to underrepresented cultural groups (West, et al., 2016). Another issue concerns the drive towards developing inclusive education within Indonesia and how any existing approaches might be used within this context. The use of extranational experts and their approaches does not have a successful record of sustaining effective teacher development within Indonesia (Allen, Hyde, Whannel, \& O'Neill, 2017). It was notable one of the 'top five' approaches was Signalong Indonesia, a keyword signing approach recently developed for inclusive Indonesian classrooms (Budiyanto et al., 2017), that supports full class communication through Bahasa Indonesia (Indonesian Language). It contrasts with the other approaches whose origins are within special education from other countries. Evaluations of teaching approaches should consider the degree to which they support or transform the practices within Indonesian inclusive classrooms. This would help acknowledge the importance of developing pedagogies within their cultural context (Tabulawa, 2013). This might include reference to the relationship between notions of happiness and pedagogy (Budiyanto et al., 2017), which is indicated in the findings.

The teachers' responses clearly indicated that they would like training in teaching children with autism, specifically training which is practical in nature and allows skill development explicitly relevant to their classroom practice. One approach mentioned by teachers as being useful in this respect was Lesson Study. 
Originating in the nineteenth century (Saito, 2012), the Lesson Study approach is well established in Japan, where it is known as Jugyokenkyu. Jugyo translates a lesson and kenkyu as study (Fernandez, 2002). It is a systematic inquiry into teaching practice through the detailed examination of lessons [kenkyujugyo "research lessons"], which offers teachers the opportunity for collaborative learning through reflection on real life class situations. Its use within Western cultures has been problematized (Fernandez, 2002; Saito, 2012; Subadi, Khotimah, \& Sutarni, 2013). But it would appear to fit well with Indonesian teacher culture (Nai, Degeng, Setyosari, \& Widiati, 2016) and its use within some sections of the Indonesian education system have had positive results as part of school-university partnerships (Hendayana, 2014), for example in relation to improving the quality of maths teaching and pupils outcomes (Nai, Degeng, Setyosari, \& Widiati, 2016). It has been particularly useful where innovation in practice is needed (Inprasitha, Isoda, Wang-Iverson, \& Yeap, 2015). Outcomes-based evaluations of Lesson Study have concluded that it can have a significant impact on the development of teachers classroom practice (Guerrero, 2014; Ó Murchú, 2011). Due to its nature it can minimize the risk of pedagogical colonization (Allen et al., 2017) and has been used successfully for teacher development in relation to teaching children with autism (Norwich \& Jones, 2014). These factors suggests that the Inclusive Classrooms Project should explore the Lesson Study approach in relation to meeting teachers explicit requests for practical real life skills development and as a vehicle for developing classrooms practices for children with autism within Indonesia.

The issue of stigmatization has been raised in relation to cultural beliefs about autism (Riany, Cuskelly, \& Meredith, 2016) and intellectual disabilities (Sheehy, Budiyanto, Kaye, \& Rofiah, 2017), and the current research supports and extends these findings. Respondents indicated that not only are children with autism stigmatized but shows, for the first time, that teachers (and parents) of autistic children can also be stigmatized. The issue of access to appropriate information about autism has been raised as a factor for influencing parent child relationships (Tehee, Honan, \& Hevey, 2009) and the current research shows that access to information in Bahasa Indonesia is associated with beliefs about stigmatization in teachers. Access to Bahas Indonesia information is also associated with belief about the school placement of children with autism (Component 3).

Cultural beliefs, such as taboo and karma, are important influences on how parents perceive autism (Riany, Cuskelly, \& Meredith, 2016), and the current research is first to identify that these issues also apply to how some teachers think about autism. Understanding the interplay between cultural beliefs, stigmatization, autism and beliefs about school placement merits further research. It would be useful to conduct in-depth teacher interviews to gain deeper insights and qualitatively delineate the nature of the cultural beliefs in the context of education. Given the exceptionally diverse nature of Indonesian society, it is likely to be useful to explore specific geographical areas, where beliefs may vary in relation to regional religious and cultural influences.

A caveat to these findings is that the participants were attending a conference on special educational needs. They therefore had a particular interest in this area 
and so their responses may not reflect those of a wider sample of teachers, who might be disinterested in this area or were already confident practitioners.

\section{Conclusion}

A purpose of the research was to inform future directions of the Inclusive Indonesian Classrooms project and, more broadly, contribute to the training of teachers of children with autism in Indonesia. This research has produced original findings about the education of children with autism within Indonesia. The data indicate that this group of children are being educated within regular, inclusive and special settings. This is occurring against backdrop in which most teachers are unfamiliar with the teaching approaches most often used with autistic children in other countries, and where taboo and stigma play a role in some stigmatizing beliefs about autism, which includes the stigmatization of teachers. The notion of using a Lesson Study approach for teacher development was suggested. There is evidence that this approach transfers well to the Indonesian context and can support the development of new culturally sensitive classroom practices. A recommendation from this research is that the Inclusive Classrooms project should pilot and evaluate this means of teacher development. Furthermore, in relation to stigmatization, there is evidence of the importance of teachers having access to information in Bahasa Indonesian. The research has elicited some specific areas for future research, which improve understanding of the interplay between Indonesian culture, pedagogies, and the education of children with autism.

\section{References}

Adinugroho, A. (2010). Recognizing and Educating Children with Special Needs (Autism and ADD).

Afrianty, D., \& Soldatic, K. (2016). Disability inclusive education in Indonesian Islamic education institution. Retrieved February 22, 2017, from http://globaldisability.org/ 2016/09/06/disability-inclusive-education-indonesian-islamic-education-institutions

Allen, W., Hyde, M., Whannel, R., \& O’Neill, M. (2017). Teacher reform in Indonesia: can offshore programs create lasting pedagogical shift? Asia-Pacific Journal of Teacher Education, O0(00), 1-16. doi:10.1080/1359866X.2017.1355051

Alqahtani, M. M. J. (2012). Understanding autism in Saudi Arabia: A qualitative analysis of the community and cultural context. Journal of Pediatric Neurology, 10(1), 15-22. doi:10.3233/JPN-2012-0527.

Aprilia, I. D. (2017). Flexible Model on Special Education Services in Inclusive Setting Elementary School. Journal of ICSAR, 1(1), 50-54. Retrieved from https://bit.ly/2M mwEK9.

Ariyanto, A. A., Muluk, H., Newcombe, P., Piercy, F. P., Suradijono, E. K. P., \& Hartati, S. R. (2017). Diversity in Unity: Perspectives from Psychology and Behavioral Sciences. Proceedings of the Asia-Pacific Research in Social Sciences and Humanities, Depok, Indonesia, November 7-9, 2016: Topics in Psychology and Behavioral Sciences. Routledge. 
Avramidis, E., \& Norwich, B. (2002). Teachers' attitudes towards integration / inclusion: a review of the literature. European Journal of Special Needs Education, 17(2), 129147. doi:10.1080/08856250210129056.

Baxter, A. J., Brugha, T. S., Erskine, H. E., Scheurer, R. W., Vos, T., \& Scott, J. G. (2015). The epidemiology and global burden of autism spectrum disorders. Psychological Medicine, 45(3), 601-13. doi:10.1017/S003329171400172X.

Beavers, A. S., Lounsbury, J. W., Richards, J. K., Huck, S. W., Skolits, G. J., \& Esquivel, S. L. (2013). Practical Considerations for Using Exploratory Factor Analysis in Educational Research. Practical Assessment, Research \& Evaluation, 18(6), 1-13.

Bella, A. (2018). Persons with Disabilities (PWD) and Poverty in Indonesia. Malaysian Journal of Economic Studies, 55(2), 167-188.

Bond, C., Symes, W., Hebron, J., Humphrey, N., \& Morewood, G. (2016). Educating Persons with Autistic Spectrum Disorder: A Systematic Literature Review. (Research Report; Vol. 20). Trim: National Council for Special Education.

Bondy, A. (2012). The unusual suspects: Myths and misconceptions associated with PECS. The Psychological Record, (1957), 789-816. Retrieved from https://bit.ly/ 2S5UY86.

British Psychological Society. (2014). Code of Human Research Ethics. British Psychological Society.

Budiyanto. (2011). Best Practices of Inclusive Education in Japan, Australia, India and Thailand: Implications for Indonesia. Tsukuba, Japan. Centre for Research in Comparative Education.

Budiyanto, Sheehy, K., Kaye, H., \& Rofiah, K. (2017). Developing Signalong Indonesia: issues of happiness and pedagogy, training and stigmatisation. International Journal of Inclusive Education, 22(5), 543-559.

Cassady, J. M. (2011). Teachers' attitudes toward the inclusion of students with autism and emotional behavioral disorder. Electronic Journal for Inclusive Education, 2(7), $1-23$.

Dempsey, I., \& Foreman, P. (2001). A Review of Educational Approaches for Individuals with Autism. International Journal of Disability, Development and Education, 48(1), 103-116. http://doi.org/10.1080/10349120120036332

Department of Economic and Social Affairs. (2011). Disability convention gets 100th ratification. Retrieved from https://bit.ly/2FRyb9N.

Department of Health. (2013). Autism and Asperger syndrome. Retrieved from https://bit.ly/2yGL14b.

Direktorat Pembinaan Sekolloah. (2008). Profil Pendidikan Inklusif di Indonesia [Inclusive Education Profile in Indonesia 1]. Jakarta: Kementerian Pendidikan Nasional.

Epstein, J., Osborne, R. H., Elsworth, G. R., Beaton, D. E., \& Guillemin, F. (2015). Crosscultural adaptation of the Health Education Impact Questionnaire: Experimental study showed expert committee, not back-translation, added value. Journal of Clinical Epidemiology, 68(4), 360-369. doi:10.1016/j.jclinepi.2013.07.013.

Febrian K., I., \& Widavant, C. G. (2015). A Survey of Autism in an Early Childhood Teacher's District of Central Java. In HardaniWidhiastuti (Ed.), Psychological Transformation towards Developing Characterized Human Being. $1^{\text {st }}$ International Conference of Psychology. Semarang: Semarang Private University.

Fernandez, C. (2002). Learning from Japanese Approaches to Professional Development: The Case of Lesson Study. Journal of Teacher Education, 53(5), 393-405. doi: $10.1177 / 002248702237394$. 
Fithri, H. (2011). Religious therapy as one of an alternative ways in getting educational betterment for children with autism spectrum disorder. Procedia - Social and Behavioral Sciences, 29, 1782-1787. doi.org/10.1016/j.sbspro.2011.11.425

Greenspan, S. I., \& Wieder, S. (1997). Developmental Patterns and Outcomes in Infants and Children with Disorders in Relating and Communicating: A Chart Review of 200 Cases of Children with Autistic Spectrum Diagnoses. The Journal of Developmental and Learning Disorders, 1(1), 1-38. doi.org/WHO/EIP/GPE/CAS/01.3

Guerrero, S. (2014). Teacher change and project maths: implications and lessons learned. Bulletin of the Irish Mathematical Society, 74(74), 27-66.

Guldberg, K., Parsons, S., MacLeod, A., Jones, G., Prunty, A., \& Balfe, T. (2011). Implications for practice from 'International review of the evidence on best practice in educational provision for children on the autism spectrum.' European Journal of Special Needs Education, 26(1), 65-70.

Hendayana, S. (2015). Teacher learning through Lesson Study in Indonesia. In K. Wood \& S. Sithamparam (Eds.), Realising learning: Teachers' professional development through lesson and learning study (pp. 62-77). London; New York: Routledge.

Herring, P., Kear, K., Sheehy, K., \& Jones, R. (2017). A virtual tutor for children with autism. Journal of Enabling Technologies, 11(1), 19-27. doi:10.1108/JET-01-20160006

Hiebert, J., Morris, A. K., \& Glass, B. (2003). Learning to learn to teach: an "experiment" model for teaching and teacher preparation in mathematics. Journal of Mathematics Teacher Education, 6(3), 201-222. doi:10.1023/A:1025162108648.

Inprasitha, M., Isoda, M., Wang-Iverson, P., \& Yeap, B. H. (2015). Lesson study: Challenges in mathematics education. World Scientific.

Jauhari, M. N. (2017). Pengembangan simbol Signalong Indoesia sebagai media (Developing Signalong Indonesia's communication symbols). In International conference on Special Education in Southeast Asia region (pp. 411-416). Malang: ICSAR.

Jordan, R., Jones, G., \& Murray, D. (1998). Educational interventions for children with autism: A literature review of recent and current research. Retrieved from http:// dera.ioe.ac.uk/15770/1/RR77.pdf

Larkin, A. S., \& Gurry, S. (1998). Brief Report: Progress Reported in Three Children with Autism Using Daily Life Therapy. Journal of Autism \& Developmental Disorders, 28(4), 339-342. doi:10.1023/A:1026068821195

Lestari, L., Herini, E. S., \& Gamayanti, I. L. (2017). Main Caregiver's Experience in Meeting Self-Care Needs among Adolescents with ASD in Pontianak Municipality, West Borneo, Indonesia: A Qualitative Study. Belitung Nursing Journal, 3(4), 316328.

Littleton, K., \& Mercer, N. (2013). Educational dialogues. In K. Hall, T. Cremin, B. Comber, \& L. C. Moll (Eds.), British Journal of Educational Technology (Vol. dbook of R). Oxford: Wiley Blackwell (In Press). Retrieved from http://oro.open.ac. $\mathrm{uk} / 31351 /$.

Makrygianni, M. K., Gena, A., Katoudi, S., \& Galanis, P. (2018). The effectiveness of applied behavior analytic interventions for children with Autism Spectrum Disorder: A meta-analytic study. Research in Autism Spectrum Disorders, 51(March), 18-31. doi.org/10.1016/j.rasd.2018.03.006

MacCallum, R.C., Widaman, K.F., Zhang, S., \& Hong, S. (1999). Sample size in factor analysis. Psychological Methods, 4(1), 84-99.

McGee, J.J., \& Brown, M. (1988). A Gentle Teaching Primer. Saskatchewan Alternative Inititiatives. Saskatchewan Alternative Inititiatives. Retrieved from https://bit.ly/ 2Ukswgh. 
Mesibov, G.B., \& Shea, V. (2010). The TEACCH program in the era of evidence-based practice. Journal of Autism and Developmental Disorders, 40(5), 570-579.

Ministry of Education and Culture. (2012). Kemdikbud (Ministry of Education and Culture) Builds Autism Centers in 29 Locations. Retrieved January 10, 2017, from https://www.kemdikbud.go.id/main/blog/2012/11/kemdikbud-akan-bangun-autiscenter-di-29-lokasi-861-861-861

Mire, S.S., Gealy, W., Kubiszyn, T., Burridge, A. B., \& Goin-Kochel, R.P. (2017). Parent Perceptions About Autism Spectrum Disorder Influence Treatment Choices. Focus on Autism and Other Developmental Disabilities, 32(4), 305-318.

Nai, F. A., Degeng, I. N. S., Setyosari, P., \& Widiati, U. (2016). Teaching Material Development of Learning and Teaching Course through Lesson Study Application for University Students. In Education in the 21th Century: Responding to Current Issues (pp. 273-283). Universitas Negeri Malang.

Ó Murchú, F. (2011). Team-teaching for inclusive learning: Purposes, practices and perceptions of a team-teaching initiative in Irish post-primary schools. Retrieved from https://bit.ly/2RFp8Qp.

OECD. (2009). Creating Effective Teaching and Learning Environments: First results from TALIS 2008. Retrieved from https://bit.ly/2Dt6ZfX.

Ottenbacher, K. (1982). Sensory Integration Therapy : Affect or Effect. American Journal of Occupational Therapy, 36(9), 571-578.

Padmadewi, N. N., \& Artini, L. P. (2017). Teaching English to a student with autism spectrum disorder in regular classroom in Indonesia. International Journal of Instruction, 10(3), 159-176. doi:10.12973/iji.2017.10311a

Pajareya, K., \& Nopmaneejumruslers, K. (2011). A pilot randomized controlled trial of DIR/Floortime ${ }^{\mathrm{TM}}$ parent training intervention for pre-school children with autistic spectrum disorders. Autism, 15(5), 563-577. doi.org/10.1177/1362361310386502

Purbani, W. (2013). Equity in the Classroom: The System and Improvement of Inclusive Schools in Yogyakarta, Indonesia (A Case Study). US-China Education Review B, 3(7), 507-518.

Ramos-Mattoussi, F., \& Milligan, J. A. (2013). Building research and teaching capacity in Indonesia through international cooperation. New York: Institute of International Relations (IIE). Retrieved from www.iie.org/cip

Riany, Y., Cuskelly, M., \& Meredith, P. (2016). Cultural beliefs about autism in Indonesia. International Journal of Disability, Development and Education, 63(6), 623-640. doi:10.1080/1034912X.2016.1142069.

Rix, J., Sheehy, K., Fletcher-Campbell, F., Crisp, M., \& Harper, A. (2013). Continuum of Education Provision for Children with Special Educational Needs: Review of International Policies and Practices. Dublin. National Council for Special Education.

Rix J, Hall, K., Nind, M., Sheehy K, \& Wearmouth J. (2006). A systematic review of interactions in pedagogical approaches with reported outcomes for the academic and social inclusion of pupils with special educational needs. In Research Evidence in Education Library. London: EPPI-Centre, Social Science Research Unit.

Roberts, J.M.A., \&Williams, K. (2016) Autism spectrum disorder: Evidencebased/evidence-informed good practice for supports provided to preschool children, their families and carers. Report prepared for the National Disability Insurance Agency (NDIA).

Roth, I. (2017). Autism: a cross-cultural perspective on service provision and capacity building. The Knowledge Exchange Seminar Series 2015-16. Retrieved March 29, 2017, from https://bit.ly/2Ud6RXw. 
Saito, E. (2012). Key issues of lesson study in Japan and the United States: a literature review. Professional Development in Education, 38(5), 777-789. doi:10.1080/1941 5257.2012.668857

Sakya, K. A., Santosa, I., \& Bagus, A. (2017). Sensitivity of Children with Autism towards children with autism towards the interior design elements in Bandung City, Indonesia. International Journal of Social Sciences, 49(1), 73-82.

Sheehy, K., \& Budiyanto. (2014). Teachers' attitudes to signing for children with severe learning disabilities in Indonesia. International Journal of Inclusive Education, 18(11). doi:10.1080/13603116.2013.879216

Sheehy, K., \& Budiyanto. (2015). The Pedagogic Beliefs of Indonesian Teachers in Inclusive Schools. International Journal of Disability, Development and Education, 62(5), 469-485. doi:10.1080/1034912X.2015.1061109.

Sheehy, K., Budiyanto, Kaye, H., \& Rofiah, K. (2017). Indonesian teachers' epistemological beliefs and inclusive education. Journal of Intellectual Disabilities, 174462951771761. doi:10.1177/1744629517717613

Sheehy, K., Rix, J., Fletcher-Campbell, F., Crisp, M., \& Harper, A. (2013). Conceptualising Inclusive Pedagogies: Evidence from International Research and the Challenge of Autistic Spectrum. Transylvanian Journal of Psychology, XIV(1), 5265. .

Sidjaja, F., \& Newcombe, P. (2016). The Diagnosis of Autism Spectrum Disorder in Urban Indonesia: A Brief Report. International Journal of Disability, Development and Education, 64(1), 33-44. doi:10.1080/1034912X.2016.1162768.

Subadi, T., Khotimah, R. P., \& Sutarni, S. (2013). A Lesson Study as a Development Model of Professional Teachers. International Journal of Education, 5(2), 102-114. doi:10.5296/ije.v5i2.3831.

Sumner, C. (2015). Indonesia's Missing Millions: Erasing Discrimination in Birth Certification in Indonesia CGD Policy Paper 064 June 2015, (June). Retrieved from https://bit.ly/2Wph1Gd.

Suwaryani, N. (2008). Policy analysis of education provision for disabled children in Indonesia: a case study of eight primary schools in Kecamatan Jatiwulung. PQDTUK \& Ireland. Retrieved from https://bit.ly/2HsEvXK.

Tabulawa, R. (2013). Teaching and learning in context: Why pedagogical reforms fail in Sub-Saharan Africa. Dakar: CODESRIA.

Tehee, E., Honan, R., \& Hevey, D. (2009). Factors Contributing to Stress in Parents of Individuals with Autistic Spectrum Disorders. Journal of Applied Research in Intellectual Disabilities, 22(1), 34-42.

Tekola, B., Baheretibeb, Y., Roth, I., Tilahun, D., Fekadu, A., Hanlon, C., \& Hoekstra, R. A. (2016). Challenges and opportunities to improve autism services in low-income countries: lessons from a situational analysis in Ethiopia. Global Mental Health, 3(21). doi:10.1017/gmh.2016.17

Tucker, A. C. (2013). Interpreting and Treating Autism in Javanese Indonesia. Los Angeles: University of California.

Tucker, C. J., Finkelhor, D., Turner, H., \& Shattuck, A. (2013). Association of sibling aggression with child and adolescent mental health. Pediatrics, 132(1), 79-84. doi:10.1542/peds.2012-3801

UNESCO. (2009). Towards Inclusive Education for Children with Disabilities: A Guideline. Bangkok, Thailand: UNESCO Bangkok. Retrieved from https://bit.ly/1M RZfmd

West, E. A., Travers, J. C., Kemper, T. D., Liberty, L. M., Cote, D. L., McCollow, M. M., \& Stansberry Brusnahan, L. L. (2016). Racial and Ethnic Diversity of Participants in Research Supporting Evidence-Based Practices for Learners with Autism Spectrum 
Disorder. The Journal of Special Education, 50(3), 151-163. doi:10.1177/00224669 16632495

Wibowo, S. B., \& Muin, J. A. (2018). Inclusive Education in Indonesia: Equality Education Access for Disabilities. KnE Social Sciences, 3(5), 484. doi.org/10.18502/ kss.v3i5.2351.

Wignyosumarto, S., Mukhlas, M., \& Shirataki, S. (1992). Epidemiological and clinical study of autistic children in Yogyakarta, Indonesia. The Kobe Journal of Medical Sciences, 38(1), 1-19. Retrieved from https://bit.ly/2sG39tt.

Williams, K. R. (2006). The Son-Rise Program ${ }^{\circledR}$ intervention for autism: Prerequisites for evaluation. Autism, 10(1), 86-102. http://doi.org/10.1177/1362361306062012

Windiani, I.G.A.T., Soetjiningsih, S., Adnyana, I.G.A.S., \& Lestari, K.A. (2016). Indonesian Modified Checklist for Autism in Toddler, Revised with Follow-Up (MCHAT-R/F) for Autism Screening in Children at Sanglah General Hospital, BaliIndonesia. Bali Medical Journal, 5(2), 133. doi:10.15562/bmj.v5i2.240. 


\section{Appendix}

Appendix 1. Questionnaire Items (Without Response Scales or Open Response Spaces)

1. What is your current occupation?

2 If you work in a school, what type of school is it?

3 Meaningful learning takes place when individuals are engaged in social activities

4. Children learn best through collaborative activities

5. Children with autism learn most effectively in a specialist setting, alongside others who have similar needs

6. Autistic children learn best from tasks with clear, correct answers

7. Students' educational potential is fixed at birth

8. Students who begin school with 'average' ability remain 'average' throughout school

9. Children with special educational needs learn most effectively in a special school not in a regular school

10. Regular teachers need special training to teach children with autism

11. All children have a right to education with their peers

12. To learn effectively children must be happy- Senang

13. To learn effectively children must be happy- Suka

14 I have met teachers who believe that autism is caused by

- Breaking a taboo

- Karma

15

- Parents are stigmatised by their community if they had a child with autism

- Teachers are stigmatised by their community if they teach children with autism

16 Many different teaching and medical approaches have been used for children with autism. Please tick below to indicate if you have been trained in, used without training, heard of or not heard of these approaches

- ABA or Lovaas Therapy

- Biomedical Intervention

- Chinese alternative medicines

- Javanese folk healing

- Religious intervention

○ TEACCH

- Floor time

- Son-Rise

- PECS (Picture Exchange Communication System)

- Signalong Indonesia

- Sensory Integration

- Gentle teaching 
- Daily Life Therapy

Q17 I have had contact with children with autism

- as part of my professional work

- outside of my professional work

Q18 I am able to access the materials that I need about autism and teaching children with autism written in Bahasa Indonesia

Q19 Do you feel you have the skills to teach a child with autism? (Yes/No)

Q20 Children with autism.

- Can learn well in mainstream classes, with appropriate support

- should be taught in special schools

- have special talents and abilities

Q21 Currently, a family's income determines

- their child's access to diagnosis

- their autistic child's access to a suitable education

Q22 What sort of training or information would be most helpful to you to support children with autism in your school? 